\title{
IN MEMORIUM: THE CONTRIBUTION of Dr. Arthur Wesley Cragg
}

\author{
Mark S. Schwartz ${ }^{1}$
}

AN INVITED TRIBUTE TO THE LATE CANADIAN BUSINESS ETHICS PIONEER

\section{Abstract}

The author comments on two journal articles authored by his former $\mathrm{PhD}$ supervisor, Dr. Arthur Wesley Cragg.

ArThur Wesley Cragg (1941-2017; hereinafter 'Wes'), was my $\mathrm{PhD}$ supervisor during 1993-99 at the Schulich School of Business, at York University in Toronto, Canada. This is my personal tribute to his memory. Before providing an overview of only two of Wes's many academic journal articles, I provide a brief summary of his significant professional contribution to the business ethics field.

Wes was a graduate of the University of Alberta (MA) and the University of Oxford (BPhil, DPhil), where he was a Rhodes Scholar. After serving as a full professor of philosophy at Laurentian University in Sudbury, Ontario, Wes joined the Schulich School of Business at York University in 1992 and was appointed the inaugural George R. Gardiner Professor of Business Ethics - the first appointment of its kind in Canada. Wes was the first director of the George R. Gardiner Program in business ethics, aiming to develop a business ethics component for Schulich's MBA program. During his tenure at Schulich, Wes supervised twenty-six graduate (Masters and $\mathrm{PhD}$ ) students. According to former Schulich Dean Dezsö J. Horváth:

Dr. Cragg's work was pioneering at a time when business schools had historically embraced shareholder primacy and a purely economic view of

\footnotetext{
1 York University. Email: schwartz@yorku.ca
} 
the firm. The introduction of ethical considerations was initially met with substantial resistance, but he persevered, establishing himself as one of the world's leading authorities in the field of business ethics (YFile 2017).

In addition to his extensive teaching of business ethics, Wes published more than seventy-five articles in Canadian and international journals, and wrote or edited fourteen books. His scholarly works covered a wide range of topics, including corporate social responsibility (CSR), corporate codes of ethics, corporate governance, sustainability, business and human rights, ethical investment, environmental ethics, the ethics of extractive industries, and economic development affecting First Nations communities. Wes served on the editorial boards of several international academic journals including the Journal of Business Ethics and Business Ethics Quarterly. Wes was involved with several business ethics organizations, including as founding chair and president of the Canadian chapter of Transparency International, as well as serving as the project director and principal investigator for the Canadian Business Ethics Research Network.

I now provide a brief treatment of only two of Dr. Cragg's journal articles, addressing the teaching of business ethics along with business ethics research.

\section{"Teaching Business Ethics: The Role of Ethics in Business and in Business Education” (Cragg 1997)}

Initially presented by Wes at his inaugural lecture at York University in 1996 and later published in the Journal of Business Ethics, the main thrust of this article was to suggest that the principal function of business ethics is to facilitate cooperation versus an emphasis on competition. People must be prepared to respect rules, otherwise cooperation becomes difficult if not impossible. According to Wes, there are three basic dimensions of ethics: (1) rules which are the 'ethics of doing' (i.e., outputs or action, what we do); (2) what we see and how we see it (i.e., inputs: perception, vision, awareness, insight); and (3) who we are or the 'ethics of being' (i.e., character formation). The focus of teaching business ethics has been mainly placed on the 'ethics of doing' and the 'ethics of being' dimensions. Wes, however, believed that it is the 'what we see and how we see it' dimension that is the most important to the modern world of business. 
Unfortunately, for those teaching business ethics there are two common responses: (1) Business ethics, isn't that an oxymoron?; and (2) While ethics may have a crucial place in business, is it really something that can be taught? Wes took a firm stance, arguing that yes, ethics and values can be taught, and that the non-committal or relativistic moral stance of many university teachers of business ethics (along with many business ethics course materials) must be avoided. Managers who accept that business ethics can't be taught tend to believe that when employees join a firm they are either ethical or they are not, and there is very little business or business schools can do about it. As a result, given that people engage in business in order to make money, the interests or well-being of others is unlikely to assume a high priority, unless one can demonstrate a direct connection between acting in an ethical manner and increasing wealth.

Wes saw a direct conflict between ethics, where the focus is on people and their rights and welfare (i.e., based on the 'golden rule'), and business, with its focus on profits (i.e., based on caveat emptorbuyer beware). For him, both ethics and business are about both people and profits. Cooperation is essential for competition, and genuine competition relies on the willingness of people to be truthful or honest while exchanging information. There would be no point to dishonesty if we did not expect people to tell the truth most of the time. Business success should be a function of the capacity of a business to facilitate and encourage cooperation-meaning that we should expect those businesses that take ethics seriously to be more likely to succeed than those that do not. There will be no resistance to ethical business practice when enhanced with the pursuit of profit, or no obvious or serious costs.

It is difficult to take much issue with Wes's essential argument in this paper. It's an important article for anyone involved in the teaching of business ethics to read. Quite often one can find business ethics professors only or primarily focusing on the 'good business ethics is good business' argument to try to persuade skeptical business students of business ethics' relevance. Wes's main concern, however, is that if students accept this argument and act ethically only or even primarily in order to enhance profits, what happens when clearly the only profitable decision is to act unethically? In such cases, if students remain focused primarily on the bottom line, would they not then naturally 
default to act unethically? Based on Wes's guidance, one should primarily teach business ethics based on a single perspective-that companies and their agents should act in an ethical manner simply because it is the right thing to do. Only in addition to this should professors also indicate and provide evidence that acting in an ethical manner tends to be good business as well.

\section{"The State and Future Directions of Business Ethics Research and Practice” (Cragg 2010)}

In this very short Business Ethics Quarterly piece, Wes shifted his focus to business ethics research. He makes it clear that for him, business ethics is dominated by two paradoxes. First, ethics is seen as playing a more important or prominent role than at any other time in business history. Yet at the exact same time, it is unlikely that there has been any other time when unethical business practice has had an impact so damaging on so many individuals all around the world. As evidence, Wes refers to the major business ethics scandals taking place at the beginning of this century: Enron, WorldCom, Arthur Andersen, the collapse of banks, and the significant negative impact all of this had on society.

While Wes is certainly correct that there have been several significant business ethics scandals in recent business history causing major societal damage, there can also be no denying that unethical scandals and activity have occurred since the very beginning of commercial activity. What Wes may have been pointing out, however, is that business ethics has never had as prominent a position in both academia and broader society, especially given the roles that the media, film (e.g., Wall Street, Boiler Room, The Insider, The Wolf of Wall Street), and literature have played in highlighting its importance.

Pointing out the emergence of business ethics research, in a somewhat sobering note Wes states that ". . . there is very little evidence that the business ethics literature is having any significant impact on either the practice or the theory of management.” According to Wes, with the focus of management practice and theoretical research remaining essentially based on maximizing share value in the short-term, ethics has unfortunately been left as a tertiary 'luxury' to be engaged in, at best. 
Given however the current predominance of corporate compliance and ethics programs including codes of ethics, ethics training, whistleblowing hotlines, and ethics officers, Wes may have understated the relatively significant impact business ethics has actually had on management 'practice'. It's also not completely clear that business ethics hasn't and isn't continuing to have a significant impact on 'management theory'. One can argue that even the earliest prominent management theorists (e.g., Frederick Taylor, Chester Barnard, Peter Drucker, and more recently Michael Porter) have each incorporated business ethics in their contributions.

Wes also indicates that alternative concepts such as corporate social responsibility and sustainability are "ironic illustrations" of these paradoxes, as each concept has over time eschewed references to their ethical foundations, with each becoming more focused on the firm's financial interests. Although Wes is certainly correct, this concern should not necessarily be seen as being problematic. One might even applaud and endorse this shift, given the bottom-line pragmatic realities of the business world. In addition, the 'good ethics is good business' argument of which Wes appears to be critical has led to and will likely continue to lead to the important ultimate goal of enhanced business ethics practice.

Near the end of his article, Wes lays out a stunning prophesy, that if business ethics is not eventually and explicitly integrated into strategic and operational management, we will be left to either abstract normative analysis detached from the real world of business, or that business ethics will consist merely of an empirical research stream dedicated to discovering the value of ethics to the bottom line. Wes concludes by observing: "Which path business ethics research and practice will take remains at this juncture impossible to predict" (Cragg 2010: 721). Fortunately, however, Wes's prophesy (or any concern related to it) does not appear to have materialized, given the extent to which business ethics has actually been incorporated into the real world of business.

Wes's call for the further integration of business ethics into mainstream management research is worth heeding. While there may be an inherent bias against and resistance to the notion of ethics being integral to management research, ignoring ethics in business research would leave a significant and unfortunate (if not dangerous) void. 


\section{Final Personal Note}

As a $\mathrm{PhD}$ student of his, I learned two very important lessons (among many) from Wes. First, as an academic, research is just as important a contribution to academia and to society as teaching. Second, business ethics should not be taught merely in instrumental 'good ethics is good business' terms. Although often the case, this may not always be the case-particularly in the short term (i.e., ethics can cost). Business students need to be prepared to address the conflict of ethics and profits when it inevitably arises. More important, for Wes, one should be ethical in business not because it may be profitable doing so, but instead be ethical for ethics' sake. I have not forgotten and will not forget the many lessons of my teacher (and friend), Dr. Wesley Cragg.

Received 11 March 2021 / Posted 3 June 2021

\section{REFERENCES}

Cragg, A. W. 2010. "The State and Future Directions of Business Ethics.” Bus Ethics Q 20(4): 720-721, https://www.jstor.org/stable/25763045

Cragg, W. 1997. "Teaching Business Ethics: The Role of Ethics in Business and in Business Education.” J Bus Ethics 16(3): 231-245, https://doi.org/10.1023/A:1017974908203

YFile. 2017. "Passings: Schulich School of Business Professor Emeritus Wes Cragg” (August 30), https://yfile.news.yorku.ca/2017/08/30/passings-schulich-school-ofbusiness-professor-emeritus-wes-cragg/ 